\title{
THE PRIVILEGES AND IMMUNITIES OF FEDERAI CITIZENSHIP AND COLGATE v. HARVEY
}

\section{Pendleton Howard $\dagger$}

In the sixty-two years intervening between the decision of the Supreme Court of the United States in the celebrated Slaughter-House Cases $^{1}$ and the recent pronouncement of the same tribunal in Colgate $v$. Harvey, ${ }^{2}$ it had been generally supposed by constitutional commentators that the privileges and immunities clause of the Fourteenth Amendment $^{3}$ was a dead letter-an innocuous declaration of fundamental rights more forcefully and adequately guaranteed in other clauses of the Constitution. In no less than forty-five cases fought out during this period, the Supreme Court had been asked to invalidate state legislation on the ground that it abridged the privileges and immunities of citizens of the United States; and in none of them could it detect any violation of the fundamental law. ${ }^{4}$ Even the basic guaranties of the so-called Bill of Rights, safeguarded from federal infringement by the first eight amendments, have been repeatedly held not to be protected by the privileges and immunities clause against challenged state statutes. $^{5}$ Yet in Colgate v. Harvey the Court discovered that a state income tax law which subjected to a 4 per cent. tax interest derived from money loans, except loans made within the state where the rate of interest was not more than 5 per cent., was invalid as an abridgement of a privilege of federal citizenship: the right to lend money in a state other than that in which the citizen resides, free from discriminatory taxation by the latter state. The case was crowded out of the spotlight by several other decisions invalidating important New Deal legislation decided during the same term of court and has not received the critical attention its importance justifies.

The surprising character of this decision, the novelty of its implications, the far-reaching threat to state power and the corresponding expansion of judicial supremacy which it seems to presage, the im-

$\dagger$ A. B., I92I, A. M., I924, Ph.D., I93r, Columbia University ; LL. B., I917, University of Texas; member of the Texas, New York, and Idaho Bars; Dean and Professor of Law at University of Idaho College of Law; author of CRIMINAL LAw IN ENGLAND: A Study IN LAW AdMINISTRATION (I93I), and articles in legal periodicals.

I. 83 U. S. 36 (I873).

2. 296 U. S. 404 (I935), 36 CoL. L. Rev. 669, 30 IlL. L. Rev. 953, 34 MICE. L. Rev. I034, 20 MINN. L. REv. 549, I4 TEX. L. REv. 548, 3 U. OF CHI. L. REv. 506, 84 U. of PA. L. Rev. 655, 45 Yale L. J. 926 (I936). See also Notes (I936) 24 CALIF. L. REv. 728,49 HARv. L. REv. 935 .

3. The clause reads as follows: "No state shall make or enforce any law which shall abridge the privileges or immunities of citizens of the United States ; . . "

4. See infra note 3 I.

5. The cases are listed infra notes 25-30. 
portant questions it leaves unanswered-all these considerations invite a reëxamination of this almost forgotten clause of the Fourteenth Amendment in the light of the cases in which it has been invoked in the past, the judicial construction heretofore given to it and the possible consequences of its broadened interpretation in this latest expression of the Court's will.

The Fourteenth Amendment to the Federal Constitution became operative July 28, I868. On April 14, I873, in the Slanghter-House Cases, it was first interpreted by the Supreme Court. The facts of these well-known cases may be briefly recalled. A Louisiana statute chartered a private corporation, giving to it the exclusive right to establish and maintain stock-yards, landing places and slaughter houses in the city of New Orleans and providing that all animals intended for food should be slaughtered there. It was the duty of the new corporation to permit any person to slaughter in its houses at charges restricted by the statute. The law was passed under the guise of protecting the public health and provided for inspection by a state inspector of all animals intended to be slaughtered. The butchers of New Orleans contended that the Act violated the Fourteenth Amendment in that it deprived persons of liberty and property.without due process of law, denied to them the equal protection of the laws and abridged the privileges and immunities of citizens of the United States. The Court sustained the statute. Speaking for the majority, Mr. Justice Miller brushed aside the due process clause contention with the observation that "the argument has not been much pressed in these cases" and that "under no construction of that provision that we have ever seen, or any that we deem admissible, can the restraint imposed by the State of Louisiana upon the exercise of their trade by the butchers of New Orleans be held to be a deprivation of property within the meaning of that provision." 6

The privileges and immunities clause was the principal bone of contention. The plaintiffs' argument, which failed to convince a majority of the Court, had run along these lines: the individual, as a citizen of a state, had, before the adoption of the Fourteenth Amendment, certain fundamental rights, privileges and immunities which were embraced in the principles of the common law and defined by state constitutions and statutes; by that Amendment the citizen became primarily a citizen of the United States, and only secondarily, by residence, a citizen of a particular state; therefore, the fundamental rights, privileges and immunities which formerly attached to him as a citizen of the state in which he lived now belonged to him as a citizen of the United

6. 83 U. S. at $80-8 \mathrm{I}$. 
States, and, by force of the Amendment, were no longer subject to abridgement by the states. Only by this construction, it was maintained, could the privileges and immunities clause be given any binding effect whatsoever. This argument, of course, put squarely before the Court the fundamental question whether or not the adoption of the Fourteenth Amendment had placed the so-called "police powers" of the states within the direct legislative definition and control of the Federal Government, since by the Amendment Congress was authorized to enforce its provisions by appropriate legislation. If the Court had construed the right alleged to have been violated as a federal right, Congress would have been empowered to define it, and all other rights of a similar nature, to impose penalties for their violation, and thus to invade the wide domain of state police power. As Professor W. W. Willoughby puts it, "To have granted the contention of the plaintiffs would thus have made Congress, instead of the state legislatures, the possible source of the great body of private laws by which the citizen is governed." 7

Mr. Justice Miller repudiated this construction of the privileges and immunities clause in no uncertain terms. He pointed out that the Fourteenth Amendment implies and by its language recognizes a distinction which had always existed between state and federal citizenship, and that only privileges and immunities of citizens of the United States, and not those of citizens of the states, are safeguarded from abridgement by state legislation. "Was it the purpose of the Fourteenth Amendment," he asked, "by the simple declaration that no state should make or enforce any law which shall abridge the privileges and immunities of citizens of the United States, to transfer the security and protection of all the civil rights which we have mentioned, from the states to the Federal Government? And where it is declared that Congress shall have the power to enforce that article, was it intended to bring within the power of Congress the entire domain of civil rights heretofore belonging exclusively to the states? All this and more must follow, if the proposition of the plaintiffs in error be sound. For not only are these rights subject to the control of Congress whenever in its discretion any of them are supposed to be abridged by state legislation, but that body may also pass laws in advance, limiting and restricting the exercise of legislative power by the states, in their most ordinary and useful functions, as in its judgment it may think proper on all such subjects. And still further, such a construction followed by the reversal of the judgments of the Supreme Court of Louisiana in these cases, would constitute this Court a perpetual censor upon all legislation of the states, on

7. I Willoughby, The Constitutional Law of the United States (2d ed. 1929) 239. 
the civil rights of their own citizens, with authority to nullify such as it did not approve as consistent with those rights, as they existed at the time of the adoption of this Amendment. . . . But when, as in the case before us, these consequences are so serious, so far-reaching and pervading, so great a departure from the structure and spirit of our institutions; when the effect is to fetter and degrade the state governments by subjecting them to the control of Congress, in the exercise of powers heretofore universally conceded to them of the most ordinary and fundamental character; when in fact it radically changes the whole theory of the relations of the state and Federal governments to each other and of both these governments to the people; the argument has a force that is irresistible in the absence of language which expresses such a purpose too clearly to admit of doubt. We are convinced that no such results were intended by the Congress which proposed these amendments, nor by the legislatures of the states which ratified them." 8

Chief Justice Chase and Justices Field, Swayne and Bradley were unable to agree with this disposition of the case. In their view the restrictive definition adopted by the majority of the Court rendered the privileges and immunities clause nugatory. Thus Mr. Justice Field, in his dissenting opinion argued: "The Amendment does not attempt to confer any new privileges or immunities upon citizens, or to enumerate or define those already existing. It assumes that there are such privileges and immunities which belong of right to citizens as such, and ordains that they shall not be abridged by state legislation. If this inhibition has no reference to privileges and immunities of this character, but only refers . . . to such privileges and immunities as were before its adoption specially designated in the Constitution or necessarily implied as belonging to citizens of the United States, it was a vain and idle enactment, which accomplished nothing, and most unnecessarily excited Congress and the people on its passage. With privileges and immunities thus designated no state could ever have interfered by its laws, and no new constitutional provision was required to inhibit such interference. The supremacy of the Constitution and the laws of the United States always controlled any state legislation of that character. But if the Amendment refers to the natural and inalienable rights which belong to all citizens, the inhibition has a profound significance and consequence." 9

In the last sentence above quoted we learn the dissenting justices' conception of the true meaning of the disputed clause. The privileges and immunities protected from abridgement by the Amendment are "the natural and inalienable rights which belong to all citizens". Mr.

8. $8_{3}$ U. S. at 77-78.

9. Id. at 96 . 
Justice Field went even further. He quoted with approval from the opinion of Mr. Justice Washington in Corfield v. Coryell. ${ }^{10}$ "The inquiry is", said the justice in that case, "what are the privileges and immunities of citizens in the several states? We feel no hesitation in confining these expressions to those privileges and immunities which are in their nature fundamental; which belong, of right, to the citizens of all free governments; and which have, at all times, been enjoyed by the citizens of the several states which compose this Union, from the time of their becoming free, independent, and sovereign." 11 Mr. Justice Washington was construing the language of Article IV, Section 2, Clause I of the Constitution which provides that "the citizens of each state shall be entitled to all privileges and immunities of citizens in the several states". In Corfield v. Coryell, despite the language of the Constitution, it was held that the clause did not mean that a state must permit citizens of other states to enjoy all the rights or privileges it accorded to its own citizens but only those which were fundamental in character. Thus New Jersey might permit its own citizens to gather clams and oysters from the waters of the state and deny the privilege to citizens of other states.

In the opinion of Mr. Justice Field and the other dissenters, therefore, there were certain "fundamental" rights, privileges and immunities which belong "of right" to the citizens of the United States and which, by force of the Amendment, were now protected from abridgement by state legislation. These privileges and immunities were for the judiciary to define and delimit as the cases arose for decision. This

Io. 6 Fed. Cas. No. 3,230 (C. C. E. D. Pa. I823).

Ir. Id. at 55I. Justice Washington continued as follows: "What these fundamental principles are, it would perhaps be more tedious than difficult to enumerate. They may, however, be all comprehended under the following general heads: Protection by the government; the enjoyment of life and liberty, with the right to acquire and possess property of every kind, and to pursue and obtain happiness and safety; subject nevertheless to such restraints as the government may justly prescribe for the general good of the whole. The right of a citizen of one state to pass through, or to reside in any other state, for purposes of trade, agriculture, professional pursuits, or otherwise; to claim the benefit of the writ of habeas corpus; to institute and maintain actions of any kind in the courts of the state; to take, hold and dispose of property, either real or personal; and an exemption from higher taxes or impositions than are paid by the other citizens of the state; may be mentioned as some of the particular privileges and immunities of citizens, which are clearly embraced by the general description of privileges deemed to be fundamental; to which may be added, the elective franchise, as regulated and established by the laws or constitution of the state in which it is to be exercised. These, and many others which might be mentioned, are, strictly speaking, privileges and immunities, and the enjoyment of them by the citizens of each state, in every other state, was manifestly calculated ... 'the better to secure and perpetuate mutual friendship and intercourse among the people of the different states of the Union'." The justice was here enunciating the well-known doctrine of "natural" or "inalienable" rights in all its vague and nebulous character. Most of the rights here enumerated, as well as those specified by Mr. Justice Miller in his decision in the Slaughter-Fouse Cases, are rights not only of citizens but of all persons, guaranteed against invasion by other clauses of the Constitution. For a list of privileges and immunities, see LIEN, Provileges and Immunities of Citizens of the United States (19I3) 80-8i. 
is what Mr. Justice Miller, speaking for the majority, meant when he said that the construction favored by the minority would constitute the Supreme Court "a perpetual censor upon all legislation of the states" and "on the civil rights of their own citizens". The meaning of such vague and cabalistic words as "fundamental", "natural" and "inalienable" is of course what the courts wish to read into them.

Professor Dudley O. McGovney has pointed out in an interesting article that the justices who dissented in the Slaughter-House Cases, in accepting and making their own this "fundamental rights" definition of privileges and immunities used in interpreting Article IV, Section 2, Clause I, were fully aware of the vastly different effect which the adoption of it as a definition of privileges and immunities in the Fourteenth Amendment would necessarily have. ${ }^{12}$ Under the construction given Article IV, Section 2, Clause I, a state was not prevented from taking away from its own citizens any privilege or immunity which it had previously given or recognized. The Court had merely said to the state: Whatever fundamental privileges and immunities you grant to your own citizens, you must also grant to citizens of other states who come within your borders or transact business therein. The dissenting justices were now prepared to go a step further and incorporate this concept of "fundamental rights" into the privileges and immunities clause of the Fourteenth Amendment. In other words, if the dissenters had had their way the Court would have said to the state: There are certain "fundamental" and "inalienable" rights which in the past you have either explicitly granted your citizens or recognized by implication; we will tell you from time to time what these rights are and you cannot in the future take them away or interfere with their enjoyment.

\section{II}

That the decision in the Slaughter-House Cases rendered the privileges and immunities clause of the Fourteenth Amendment a dead letter was soon recognized by the courts and constitutional commentators. ${ }^{13}$

12. McGovney, Privileges or Imnnnities Clause, Fourteenth Amendment (rgr8) 4 Iowa I. BuLL. 219, 229.

I3. In charging a grand jury shortly after the decision Circuit Judge Emmons said: "With the fact that this interpretation was equivalent to expunging it [the privileges and immunities clause] from the amendments altogether we have nothing to do. It is true, unquestionably, that any violation of any privilege or immunity protected by the federal constitution, by the state, could be punished and redressed by congressional law before the adoption of this amendment. As now judicially read by the court of last resort, it leaves the organic law in this regard precisely where it was before. It is one of those constructions, often resorted to, to prevent consequences serious and revolutionary, which courts believe were not contemplated by legislatures who pass laws, and by the people who adopt constitutions." 30 Fed. Cas. No. 18,260, at 1006 (W. D. Tenn. I875). See the interesting discussion in 3 WarRen, The SUPREMre Court IN UNITED States Hrstory (ig22) c. 32. See also Brannon, The Fourteenter Amendment (IgOI) 62,63 ; I WrLLougHBY, op. cit. stipra note 7 , § 136 . A still narrower construc- 
In the language of Justice Field, above quoted, it became "a vain and idle enactment, which accomplished nothing, and most unnecessarily excited Congress and the people on its passage". ${ }^{14}$ The effect of the decision was to forbid the states from abridging any privilege or immunity granted to citizens of the United States by the Federal Constitution or by federal statutes or treaties. This result, of course, had already been achieved by the "supremacy clause" of Article VI, Section 2. As a matter of fact, the supremacy clause is considerably broader in scope because it serves to protect the alien, as well as the citizen, and not merely from state legislation but from state action of any kind which infringes upon any right conferred by federal law.

Viewed from the vantage ground of intervening time, the decision in the Slanghter-House Cases seems today a lesson in judicial selfrestraint which the Supreme Court would do well to study. The farreaching, and often alarming, consequences of the Court's subsequent discovery that the due process clause of the Fourteenth Amendment could be utilized as a constitutional restraint upon the substance of legislation ${ }^{15}$ as well as upon forms and modes of procedure, and for the protection of the property of corporations as well as of natural persons, ${ }^{16}$ show what probably would have been the result if state legislation involving every possible civil right of a state citizen had been held subject to judicial veto under the privileges and immunities clause. Perhaps the fairest estimate of the judicial statesmanship of 1873 was that

tion, suggested by the language of the Court in at least two subsequent cases, is that the protection of the clause is limited to those privileges or immunities which a citizen possesses solely by virtue of his national citizenship, as necessary and exclusive concomitants of such citizenship. Thus, in Bradwell v. State, 83 U. S. I30, I39 (1873), the next case decided after the Slanghter-Honse Cases, Mr. Justice Miller said: ". . . there are privileges and immunities belonging to citizens of the United States, in that relation and character, and . . . it is these and these alone which a State is forbidden to abridge." (Italics supplied.) And in Maxwell v. Dow, I76 U. S. 581, 596 (I900), Mr. Justice Peckham used the following language: "Those are not distinctly privileges or immunities of such citizenship, where every one has the same [right] as against the Federal Government, whether citizen or not. The Fourteenth Amendment - . did not add to those privileges or immunities." This narrower construction, however, has not prevailed in the later cases; and it is doubtful if Mr. Justice Miller intended to suggest any different interpretation of the clause in Bradwell $v$. State, supra, from that laid down by him in the Slaughter-House Cases. See the careful discussion of this point by McGovney, loc. cit. supra note I2.

I4. 83 U. S. at 96.

I5. Davidson v. New Orleans, 96 U. S. 97 (1877) ; Stone v. Farmers Loan \& Trust Co., II6 U. S. 307 (I886) ; Chicago, Milwaukee \& St. Paul R. R. v. Minnesota, I34 U. S. 4 I8 (1890); Chicago, Burlington \& Quincy Ry. v. Chicago, I66 U. S. 226 (I897). It was in Davidson v. New Orleans, supra, that the Supreme Court first indulged in dicta to the effect that substantive rights of life, liberty and property are protected against legislative deprivation by the due process clause.

16. Santa Clara Co. v. Southern Pacific R. R., II8 U. S. 394 (I886) ; Covington \& Lexington Turnpike Co. v. Sandford, I64 U. S. 578 (I896) ; Smyth v. Ames, I69 U. S. 466 (I898) ; Kentucky Finance Corp. v. Paramount Auto Exchange Corp., 262 U. S. 544 (I923). 
made thirty-five years later by Mr. Justice Moody, speaking for the Court in the case of Twining $v$. New Jersey: ${ }^{17}$

"There can be no doubt, so far as the decision in the SlaughterHouse Cases has determined the question, that the civil rights sometimes described as fundamental and inalienable, which before the war Amendments were enjoyed by state citizenship and protected by state government, were left untouched by this clause of the Fourteenth Amendment. Criticism of this case has never entirely ceased, nor has it ever received universal assent by members of this Court. Undoubtedly it gave much less effect to the Fourteenth Amendment than some of the public men active in framing it intended, and disappointed many others. On the other hand, if the views of the minority had prevailed it is easy to see how far the authority and independence of the states would have been diminished, by subjecting all their legislative and judicial acts to correction by the legislative, and review by the judicial branch of the National Government." 18

Until the decision in I935 in Colgate v. Harvey, which will be discussed presently, the Supreme Court repeatedly refused to modify the position taken in the Slanghter-House Cases. The distinction there drawn between national and state citizenship and their respective privileges was firmly adhered to, and the privileges and immunities clause of the Fourteenth Amendment was consistently construed as protecting only interests growing out of the relationship between the citizen and the National Government, created by the Constitution and laws of the United States. ${ }^{10}$ For example, in McPherson $v$. Blacker ${ }^{20}$ Chief Justice Fuller said:

". . . the privileges and immunities of citizens of the United States are those which arise out of the nature and essential character of the national government, the provisions of its Constitution, or its laws and treaties made in pursuance thereof; and ... it is the latter which are placed under the protection of Congress by the second clause of the Fourteenth Amendment." 21

And as late as 1934, in Hamilton v. Regents of the University of California, ${ }^{22} \mathrm{Mr}$. Justice Butler phrased the rule as follows:

I7. 2 II U. S. 78 (Ig08).

I8. Id. at 96.

I9. Some state and lower federal court decisions have been decided upon the basis of the "fundamental rights" doctrine rejected by the Slanghter-House Cases. E. g., State v. Gilman, 33 W. Va. I46, 1o S. E. 283 (I889) ; Ruhstrat v. People, I85 IIl. I33, 57 N. E. 4 I (Ig00); Meehan v. Excise Comm'rs, 73 N. J. L. 382, 64 At1. 689 (Ig06); Strange v. Board of Comm'rs, I73 Ind. 640, 9r N. E. 242 (I9ro) ; Ratta v. Healy, I F. Supp. 669 (D. N. H. I932), appeal dismissed for want of jurisdiction, 289 U. S. 701 (I933).

20. I46 U. S. I (I892).

2r. Id. at $3 \mathrm{~s}$. Mr. Justice Moody used similar language in Twining v. New Jersey, 2II U. S. 78, 97 (I908).

22. 293 U. S. 245 (1934), 83 U. of PA. L. Rev. 529 (1935). 
"The 'privileges and immunities' protected are only those that belong to citizens of the United States as distinguished from citizens of the States-those that arise from the Constitution and laws of the United States as contrasted with those that spring from other sources." 23

In several important cases the Court was urged to interpret the privileges and immunities clause as imposing the same restrictions upon the states that the first eight amendments to the Constitution impose upon the National Government. ${ }^{24}$ But this construction, which would have resulted in the inclusion of the fundamental guaranties of personal liberty contained in the Bill of Rights among the privileges and immunities of citizens of the United States protected by the Fourteenth Amendment, has been uniformly rejected. Thus, the following have been held (either directly or in effect) not to be privileges and immunities of federal citizenship : the right of trial by jury in suits at common law, guaranteed by the Seventh Amendment; ${ }^{25}$ the right to bear arms, guaranteed by the Second Amendment; ${ }^{26}$ the right to trial by jury in criminal prosecutions, guaranteed by the Sixth Amendment; ${ }^{27}$ the guaranty against prosecution for a capital, or otherwise infamous crime, except on indictment of a grand jury, contained in the Fifth Amendment; ${ }^{28}$ the right in a criminal case to be confronted by witnesses, included in the Sixth Amendment; ${ }^{29}$ and the protection against compulsory selfincrimination, afforded by the Fifth Amendment. ${ }^{30}$

All in all, forty-five cases have gone to the Supreme Court in which the argument was advanced by counsel that the challenged state legislation infringed the privileges and immunities clause. ${ }^{31}$ In none of them was the contention upheld. The Court has held-to give some exam-

23. Id. at 26r. See also Mr. Justice Pitney's language, when speaking for the Court in Prudential Insurance Co. v. Cheek, 259 U. S. 530, 539 (I922).

24. In Twining v. New Jersey, 2 II U. S. 78, 98 (Ig08), cited supra note 17, Mr. Justice Moody said: "This view is based upon the contention . . that the safeguards of personal rights which are enumerated in the first eight Articles of amendment to the Federal Constitution, sometimes called the Federal Bill of Rights, though they were by those Amendments originally secured only against National action, are among the privileges and immunities of citizens of the United States, which this clause of the Fourteenth Amendment protects against state action. This view has been, at different times, expressed by justices of this court ... and was undoubtedly that entertained by some of those who framed the Amendment. It is, however, not profitable to examine the weighty arguments in its favor, for the question is no longer open in this court."

25. Walker v. Sauvinet, 92 U. S. 90 (1875).

26. Presser v. Illinois, II6 U. S. 252 (I886).

27. Maxwell v. Dow, 176 U. S. 58 I (1900).

28. Hurtardo v. California, IIo U. S. 516 (I884) (decision under due process clause); Maxwell v. Dow, I76 U. S. 58 I (I900).

29. West v. Louisiana, I94 U. S. 258 (I904) (decision under due process clause).

30. Twining v. New Jersey, 2II U. S. 78 (I908).

3I. See cases collected in Mr. Justice Stone's dissenting opinion in Colgate v. Harvey, 296 U. S. at 445, n. 2. Ferry v. Spokane, Portland \& Seattle Ry., 258 U. S. 314 (I922), was omitted from this list. 
ples-that it is not a privilege of federal citizenship to practice law in a state court; ${ }^{32}$ to sell or possess intoxicating liquor $;^{33}$ to vote in elections $;^{34}$ to be released from detention by state authorities after having been forcibly and illegally abducted from another state and indicted for felony; ${ }^{35}$ to be protected from a state statute substituting punishment of death by electricity for hanging; ${ }^{36}$ to be protected from a state statute providing for solitary confinement, upon conviction of a capital offense, until imposition of the death penalty; ${ }^{37}$ to carry dangerous weapons in violation of a state law; ${ }^{38}$ to be protected from a state statute providing for separate railway coaches for white and colored passengers; ${ }^{39}$ to be protected from a state statute imposing a license tax upon emigrant aliens; ${ }^{40}$ to be protected from a state transfer tax law construed as subjecting to taxation remainders created by a will before the precedent estates terminate and the remainders vest in possession; ${ }^{41}$ to use representations of the national flag upon articles of merchandise for advertising purposes $;^{42}$ to be protected from a state statute imposing upon mine owners responsibility for defaults of mine managers and mine examiners who are required to hold licenses from the state $;^{43}$ to be protected from a state statute under which a telegraph company cannot limit its liability for negligent failure to deliver a telegram to a person in another state ${ }^{44}$ to be protected from a state law allowing recovery by an injured railway employee in spite of contributory negligence, where his negligence is slight and that of the company gross ; ${ }^{45}$ to deal in junk and metals without making diligent inquiry as to their legal status $;^{46}$ to enroll as a student in a state university without renouncing previous affiliation with a college fraternity; ${ }^{47}$ to graze sheep on the federal public domain ${ }^{48}$ to attend a state university with-

32. Bradwell v. State, 83 U. S. I30 (I873); In re Lockwood, I54 U. S. II6 (I894).

33. Bartemeyer v. Iowa, 85 U. S. I29 (I874) ; Giozza v. Tiernan, I48 U. S. 657 (I893) ; Cox v. Texas, 202 U. S. 446 (I906); Crane v. Campbell, 245 U. S. 304 (1917). I (1892).

34. Minor v. Happersett, 88 U. S. I62 (I875); McPherson v. Blacker, I46 U. S.

35. Mahon v. Justice, 127 U. S. 700 (I888).

36. In re Kemmler, 136 U. S. 436 (IS90).

37. McElvaine v. Brush, I42 U. S. I55 (I89I).

38. Miller v. Texas, I53 U. S. 535 (I894).

39. Plessy v. Ferguson, I63 U. S. 537 (1896).

40. Williams v. Fears, I79 U. S. 270 (I900).

4I. Orr v. Gilman, I83 U. S. 278 (I902).

42. Halter v. Nebraska, 205 U. S. 34 (I907).

43. Wilmington Star Mining Co. v. Fulton, 205 U. S. 60 (1907). (I9ro).

44. Western Union Telegraph Co. v. Commercial Milling Co., 218 U. S. 406

45. Missouri Pacific Ry. v. Castle, 224 U. S. 541 (I9I2).

46. Rosenthal v. New York, 226 U. S. 260 (IgI2).

47. Waugh v. Board of Trustees of University of Mississippi, 237 U. S. 589 (I9I5).

48. Omaechevarria v. Idaho, 246 U. S. 343 (I9I8). 
out being required to receive instruction in military science; ${ }^{40}$ or to obtain dower rights. ${ }^{50}$

It is true, of course, that the "fundamental rights" doctrine specifically rejected in the Slaughter-House Cases later found its way into the constitutional law of the United States through its adoption by the Supreme Court in Allgeyer v. Louisiana ${ }^{51}$ as a definition of due process of law. The supposed need for more efficient judicial protection against restrictions imposed by state lawmakers in their efforts to control public utilities and curb the growing power of corporate wealth was found, after considerable hesitation, in the occult words of the due process and equal protection clauses of the Fourteenth Amendment. ${ }^{52}$ In the $\mathrm{All}$ geyer case-the first in which the Court relied upon the "liberty of contract" concept as a ground for invalidating a statute-Mr. Justice Peckham, speaking for the Court, quoted with approval expressions of $\mathrm{Mr}$. Justice Bradley in Butchers' Union Slaughter-House and Live-Stock Landing Co. v. Crescent City Live-Stock Landing and Slaughter-House $\mathrm{Co}^{53}$ which were merely repetitions of statements in his dissenting opinion in the Slaughter-House Cases. Through an increasingly elastic interpretation of the due process and equal protection clauses, many socalled "fundamental rights" have been judicially safeguarded against state action which has been characterized as "arbitrary", "capricious", or "unreasonable". It is probable that some of these rights would have been classified as privileges and immunities of national citizenship if the Slaughter-House Cases had been decided differently. It is significant, however, that prior to the decision in Colgate v. Harvey, whenever the issue of privileges and immunities under the Fourteenth Amendment was raised, the Court rigidly adhered to the definition laid down in the Slaughter-Houses Cases.

\section{III}

In Colgate v. Harvey the Supreme Court was asked to pass upon the validity of a provision of the Vermont Income and Franchise Tax

49. Hamilton v. Regents of University of California, 293 U. S. 245 (I934), 83 U. OF PA. L. REv. 529 (1935).

50. Ferry v. Spokane, Portland \& Seattle Ry., 258 U. S. 3I4 (I922).

5I. I65 U. S. 578 (1897).

52. See 3 WilloughBY, op. cit. supra note 7, c. XCI; Corwin, The Doctrine of Due Process of Law Before the Civil War (IgII) 24 HARv. L. REv. 366, 460 ; Corwin, The Supreme Court and the Fourteenth Amendinent (1909) 7 MrCH. L. REv. 643.

53. III U. S. 746, 764 (I884). Mr. Justice Field had evidently foreseen the possibilities of the due process clause in this respect much earlier since he in effect relied upon it in his dissent in Munn v. Illinois, 94 U. S. II3, I36 (I876). It was in the next term after Mumn v. Illinois was decided that Mr. Justice Bradley, in a concurring opinion in Davidson v. New Orleans, 96 U. S. 97 , 107 (I877), declared by way of dicta that the due process clause could be used as a restriction upon the substance of legislation as well as upon forms of procedure. On this subject, see Pound, Liberty of Contract (Ig09) I8 YALE L. J. 454; Reeder, The Due Process Clauses and "The Substance of Individual Rights" (I9IO) 58 U. OF PA. L. REv. I9I. 
Act of $193^{54}$ which subjected to a 4 per cent. tax interest derived from money loans, except ( $I$ ) income from loans made within the state where the rate of interest was not more than 5 per cent., and (2) corporate dividends earned within the state by corporations subject to the local franchise tax. Colgate, a resident of Vermont, contended that the 4 per cent. tax on the interest he received from loans made outside the state at a rate of interest less than 5 per cent. was discriminatory, in view of the exemption of interest from like loans made within the state, and a denial to him by the state of the equal protection of the laws guaranteed by the Fourteenth Amendment as well as an abridgement of his privileges and immunities as a citizen of the United States in contravention of the same Amendment. The Supreme Court of Vermont denied the contentions of appellant and sustained the Act. ${ }^{55}$

Speaking through Mr. Justice Sutherland, the Court first upheld the tax upon corporate dividends earned outside the state, from which tax dividends earned within the state are exempt, on the ground that the evident intent and general operation of the legislation was to adjust the tax burden with a reasonable degree of equality. After almost but not specifically deciding that the discrimination against loans made outside the state violated the equal protection guaranty, and after undertaking to answer the argument that the classification was reasonable because its aim and effect was to encourage loans within the state, the opinion finally declared this portion of the Act invalid as an infringement of the privileges and immunities clause, "quite apart from the equal protection of the laws clause". ${ }^{56}$ Pointing out that the purpose of Article IV, Section 2, Clause I of the Constitution was to require each state to accord equality of treatment to the citizens of other states in respect of the privileges and immunities of state citizenship, Mr. Justice Sutherland continued:

“. . . One purpose and effect of the privileges and immunities clause of the Fourteenth Amendment, read in the light of this interpretation, was to bridge the gap left by that article so as also to safeguard citizens of the United States against any legislation of their own states having the effect of denying equality of treatment in respect of the exercise of their privileges of national citizenship in other states. A provision which thus extended and completed the shield of national protection between the citizen and

54. Vt. Laws I93I, No. I7, p. I7.

55. 107 Vt. 28, I75 Atl. 352 (1934).

56. $296 \mathrm{U}$. S. at 426 . Most of the commentators on this case in the law reviews treat the decision as resting upon the equal protection clause as well as upon the privileges and immunities clause. See, for example (I936) 34 Mich. L. Rev. 1034, 3 U. of CHI. I. Rev. 506, 84 U. OF PA. L. REv. 655, 46 YALE L. J. 926. One thinks the opinion leaves the point doubtful. See Note (1936) 49 HARV. L. REv. 935, n. 4. It seems clear to me that, despite much discussion of the equal protection guaranty, the case is decided solely on the basis of the privileges and immunities clause. 
hostile and discriminating state legislation cannot be lightly dismissed as a mere duplication, or of subordinate or no value, or as an almost-forgotten clause of the Constitution.

"Reference has been made to numerous cases in which this court has rejected or ignored specific claims under the privileges and immunities clause; but since none of them relates to state legislation even remotely resembling the Vermont law here challenged, their collection and citation is without useful result, unless, as it seems to be thought, these numerous unsuccessful efforts to give the clause applications which fall outside its meaning show or tend to show that the clause itself has become a dead letter. Such a conclusion is, of course, inadmissible.

"It follows from what has been said that" when a citizen of the United States residing in Vermont goes into New Hampshire, he does not enter foreign territory, but passes from one field into another field of the same national domain. When he trades, buys or sells, contracts or negotiates across the state line, when he loans money or takes out insurance in New Hampshire-whether in doing so he remains in Vermont or not-he exercises rights of national citizenship which the law of neither state can abridge without coming into conflict with the supreme authority of the federal Constitution." 57

In the opinion of the majority, the power to tax income asserted by Vermont was, in the final analysis, the power to tax so heavily as to preclude loans outside the state altogether. Therefore the discriminatory tax here imposed abridged the privilege of a citizen of the United States to lend his money and make contracts with respect thereto in any part of the country.

Mr. Justice Stone wrote a vigorous dissenting opinion, concurred in by Justices Brandeis and Cardozo. "Feeble indeed," he said, "is an attack on a statute as denying equal protection which can gain any support from the almost forgotten privileges and immunities clause of the Fourteenth Amendment." 58 He recalled that the clause had consistently been construed as protecting only interests growing out of the relationship between the citizen and the National Government, created by the Constitution and federal laws. He pointed out that the protection and control of intercourse among the states, not carried on in pursuance of the relationship between the citizen and the National Government, had uniformly been left to the interstate commerce clause, to the due process and equal protection clauses of the Fourteenth Amendment, and to Article IV, Section 2, Clause I, guaranteeing to the citizens of each state the privileges and immunities of citizens in the several states. In no case since the adoption of the Fourteenth Amendment, he de- 
clared, had the privileges and immunities clause been held to afford any protection to movements of persons across state lines or other forms of interstate transaction. He continued:

"The reason for this reluctance to enlarge the scope of the clause has been well understood since the decision of the SlaughterHouse Cases. . . . If its restraint upon state action were extended more than is needful to protect relationships between the citizens and the national government, and it did more than duplicate the protection of liberty and property secured to persons and citizens by the other provisions of the Constitution, it would enlarge judicial control of state action and multiply restrictions upon it to an extent difficult to define, but sufficient to cause serious apprehension for the rightful independence of local government. That was the issue fought out in the Slaughter-House Cases ... with the decision against the enlargement. . . .

"If its sweep were now to be broadened to include protection of every transaction across state lines, regardless of its connection with any relationship between the citizen and the national government, a step would be taken, the gravity of which might well give us concern. But it is necessary to go much further before the present tax can be condemned. If protection of the freedom of the citizen to pass from state to state were the object of our solicitude, that privilege is adequately protected by the commerce clause, even though the purpose of his going be to effect insurance or transact any other kind of business which is in itself not commerce. But protection of the citizen's freedom of movement, whether by the privileges and immunities clause or by the commerce clause, will afford appellant no relief from the present tax. The record does not show that he was ever outside the State of Vermont and for aught that appears he acquired his extra-state investments, which are in the form of negotiable corporate securities, by gift or purchase in Vermont. Nor does it appear that the physical securities or payments of income of which appellant has had the benefit have crossed state lines. He can be saved from the tax only by the extension of the immunity to his income merely because the property from which it has been derived, or the corporation paying it, is located in another state." 59

\section{IV}

There seems to be little question that the majority of the Court in Colgate v. Harvey deliberately repudiated the limitations placed upon the privileges and immunities clause in the Slaughter-House Cases and reaffirmed in later decisions. That the hitherto rejected "fundamental rights" doctrine lies at the core of Mr. Justice Sutherland's thinking is apparent from a reading of his opinion. He discusses, for example, the business of insurance and says that it cannot be doubted that a citizen

59. Id. at $445-447$. 
of the United States resident in and owning property in Vermont exercises a privilege of national citizenship when he takes out in another state a policy insuring that property or insuring his life. State legislation denying the privilege or imposing a discriminatory tax on the transaction when it occurs in another state, would, he maintains, abridge that privilege of citizenship. It is no answer, in his opinion, to say that the citizen may resort to other clauses of the Fourteenth Amendment for protection. "The right of a citizen of the United States resident in one state to contract in another," he writes, "may be a liberty safeguarded by the due process of law clause, and at the same time, none the less, a privilege protected by the privileges and immunities clause of the Fourteenth Amendment. In such case he may invoke either or both. This seems to be recognized in Allgeyer $v$. Louisiana . . . where the court evidently thought that under circumstances not unlike those just suggested the words 'liberty' and 'privilege' were interchangeable terms." 60 We have seen that it was in the Allgeyer case that Mr. Justice Peckham, in defining the term "liberty" in the due process clause, quoted with approval statements of Mr. Justice Bradley in the Butchers' Union Co. case, which were merely repetitions of views previously expressed by the minority in the Slaughter-House Cases. But the Allgeyer case had held that the right of a citizen of a state to contract outside the state for insurance on his property was one protected by the due process clause from abridgement by the state; the decision did not turn on the privileges and immunities clause. Mr. Justice Peclsham had simply utilized the rejected "fundamental rights" concept in defining due process. Mr. Justice Sutherland and his colleagues are now apparently ready to use it in defining the privileges and immunities of citizens of the United States.

To say that the right protected in the Allgeyer case or in Colgate v. Harvey is one arising out of the nature and essential character of the National Government, secured to all citizens by the Constitution and laws of the United States- to use the language of the cases reaffirming the test laid down in the Slaughter-House Cases-is to stretch the meaning of language beyond reasonable limits and, in the light of previous decisions, is to achieve a result little short of absurd. Is the right to lend money in a state other than the one in which you live more sacrosanct than the right to trial by jury in a criminal prosecution or the right to be safeguarded against compulsory self-incrimination? Should the one be held to be a privilege of national citizenship, protected by the privileges and immunities clause against infringement by the state, any

6o. $I d$. at 433 . 
more than the others? The Supreme Court has answered these questions in the affirmative.

The most disquieting aspect of Colgate $v$. Harvey, however, is its uncertain scope. In holding that freedom to disregard state lines in buying securities is a privilege or immunity of national citizenship protected by the Fourteenth Amendment, does the Court mean to imply that all discriminatory state taxation of out-of-state income is to be invalidated in the future? In dealing with state action challenged under the due process and equal protection clauses, the Court has invariably used the criteria of reasonableness. In the instant case the tax was adjudged invalid "quite apart from the equal protection of the laws clause". Does the decision mean that henceforth any interstate commercial transaction may not be subject to a discriminatory tax, no matter how reasonable or justified by economic circumstances the tax may be, merely because it is labelled a privilege or immunity of national citizenship? Are the states to be faced with the criterion of absolute equality of taxation when commercial dealings across state lines are involved? If so, the rejuvenated clause will become-to use the language of Mr. Justice Stone-"an inexhaustible source of immunities, incalculable in their benefit to taxpayers and in their harm to local government. . . " 61 If so, the states are in danger of suffering a curtailment of legislative power far beyond that experienced heretofore under judicial interpretation of the Fourteenth Amendment. If, on the other hand, as seems more likely, the Court means to say that only "arbitrary" or "unreasonable" or "capricious" inequalities in the taxation of out-ofstate income are to be subjected to judicial veto, it is difficult to see how it has afforded any protection to the investor that has not heretofore been given under the equal protection clause, the benefit of which extends not only to citizens but to all persons. ${ }^{62}$

Nor does the decision appear to be needed in order to afford protection for miscellaneous interstate activities of citizens. As pointed out by Mr. Justice Stone, the commerce clause, as construed by the Supreme Court, has heretofore been considered fully adequate to safeguard the right to pass from state to state, whether for the purpose of carrying on interstate commerce or other forms of legitimate business activity not so classified. In Crandall $v$. Nevada, ${ }^{63}$ decided before the adoption of the Fourteenth Amendment and before the full scope of the commerce clause had been marked out, the privilege of leaving the state

6I. Id. at 447 .

62. It seems clear that the result in the instant case could have been reached under the equal protection clause without resort to the privileges and immunities clause. Mr. Justice Sutherland's language throughout the opinion supports such a conclusion. See supra note 56 .

63. 73 U. S. 35 (I868). 
for the purpose of approaching the seat of the National Government and transacting business with it was held to be a right of national citizenship not subject to impairment by the state of the citizen's residence. Upon this ground the Court held invalid a state capitation tax on passengers transported out of the state by railroad or stage coach. Had Crandall v. Nevada arisen at a later period it would unquestionably have been decided under the commerce clause. ${ }^{64}$ But in view of the fact that state taxation of net income derived from interstate commerce has never been held to be a burden on such commerce or an infringement of the commerce clause, it can scarcely be contended now that the privilege of carrying on interstate commercial transactions is impaired by a tax on income derived from out-of-state investments. Nor is it now open to argument that a tax on property, or the income from property, is invalid as a burden on interstate commerce simply because the property has once been, or at some time in the future may be, an article of commerce. The claim that a state tax indirectly affecting interstate transactions but not invalid under the commerce clause or under Article IV, Section 2, Clause I, should be held to constitute a violation of the privileges and immunities clause was specifically repudiated by the Court in Williams v. Fears. ${ }^{65}$ In this case a Georgia license tax upon persons engaged in hiring laborers for employment outside the state was held not to impair the privileges and immunities clause of the Fourteenth Amendment. In no decision prior to Colgate v. Harvey has the Court ever deemed it necessary to invoke the privileges and immunities clause in order to safeguard the rights of persons, whether citizens or not, to engage in legitimate activities in the several states of the Union.

Colgate v. Harvey is a reactionary decision in the sense that it expands the scope of the judicial power under the Fourteenth Amendment and seems to make possible the invalidation of every state statute thought to infringe some "fundamental right" judicially classified as a privilege or immunity of national citizenship. Indeed, if the case be subsequently construed as laying down the criterion of absolute equality in the taxation of interstate commercial transactions, it may be used by the Court in the future as a precedent for further restricting the power of the states to exercise social control over economic enterprise and industrial organization through the exertion of the taxing power.

64. "No one could doubt that if the decision [in Crandall v. Nevada] had been made at any time after Railroad Co. v. Maryland . . . and until the present moment, it would have been rested on the commerce clause." Mr. Justice Stone in his dissent in Colgate v. Harvey, 296 U. S. at 444.

65. I79 U. S. 270 (I900). 
The issues presented in such cases are, I think, too vital and controversial to make wise or expedient solutions by judicial fiat-especially a fiat announced by a divided Court in which considerations of social and economic policy often profoundly influence the results. Solutions of economic problems should come from the political branches of government rather than the courts. Legislation demonstrated to be economically unsound can be repealed or modified and a policy then adopted that will meet the tested needs of experience.

If, however, we accept the construction that the decision is based merely on the unreasonableness of the discrimination involved in the taxing policy of Vermont, Colgate v. Harvey seems to be a wholly unnecessary pronouncement because the same result could have been reached under the equal protection clause. To borrow the forceful words of Mr. Justice Stone: "If the exemption does not merit condemnation as a denial of the equal protection which the Fourteenth Amendment extends to every person, nothing can be added to the vehemence or effectiveness of the denunciation by invoking the command of the privileges and immunities clause." 68 The commerce clause, the impairment of contracts clause, and the due process and equal protection clauses, as judicially construed, furnish ample protection to business, industry and private property against the arbitrary and unreasonable exercise of state legislative power or unconstitutional attempts by the states to impose burdens on interstate commerce. It will be a result fraught with peril to democratic institutions if any portion of the social control thus far permitted under these clauses of the Constitution is denied in the future under the privileges and immunities clause.

It is of course always hazardous to predict the future course of judicial decision or the alignment of justices in the Supreme Court of the United States. Trends discernible in recent decisions validating important social legislation, however, point to another period of judicial self-restraint in dealing with the enactments of legislative bodies reminiscent of the Taney tradition. It is of some significance that two members of the Court who helped form the majority in Colgate v. Harvey -one of them the writer of the opinion-have since retired from the judicial stage. In view of the uncertain scope and precedent-shattering character of the decision, perhaps even conservatives will not greatly mourn if this product of the judicial statesmanship of 1935 is permitted to slumber in deserved repose.

66. 296 U. S. at 450 . 